\title{
The Human -Cat Relationship, Myths/Superstitions and its Consequences on Cat Ownership in Maiduguri, Northeastern Nigeria
}

\author{
Bukar-Kolo $\mathrm{YM}^{*}$, Igbokwe $\mathrm{IO}^{2}$ and Egwu GO${ }^{1}$ \\ ${ }^{1}$ Department of Veterinary Medicine, University of Maiduguri, Borno State, Nigeria \\ ${ }^{2}$ Department of Veterinary Pathology, University of Maiduguri, Borno State, Nigeria
}

*Corresponding author: Bukar-Kolo YM, Department of Veterinary Medicine, University of Maiduguri, Borno State, Nigeria, Tel: +2348057159989, E-mail: yachillabukar@gmail.com

Citation: Bukar-Kolo YM, Igbokwe IO, Egwu GO (2018) The Human -Cat Relationship, Myths/Superstitions and its Consequences on Cat Ownership in Maiduguri, Northeastern Nigeria. J Vet Sci Ani Husb 6(2): 201. doi: $10.15744 / 2348-9790.6 .201$

Received Date: January 26, 2018 Accepted Date: May 22, 2018 Published Date: May 24, 2018

\begin{abstract}
A survey was designed to determine the human-cat relationship, myths/superstition and its consequences on cat ownership in Maiduguri, Nigeria. Close ended structured questionnaires were administered to 200 households randomly selected from four wards in Maiduguri. The response rate was $98.0 \%$. Out of the 200 households, 196 (98.0\%) participated, while 4 (2.0\%) did not. Of the 196 households that took part in the survey, $168(84.0 \%)$ owned cats while $28(14.0 \%)$ did not. A total of 310 cats were owned by the 168 participating households. Elderly women owned $55.5 \%$ of the cats, while children and young ladies owned $35.0 \%$ and $3.5 \%$ respectively. Only 1 cat was neutered, while the remaining 309 (99.7\%) were intact. The cats were kept for the purpose of companionship and rodent control. All the cats were of non-specific breed and had never been vaccinated against any specific disease(s). Some cat owners in Maiduguri believed in myths/superstitions associated with the domestic house cat. However, it was concluded that households in Maiduguri viewed keeping cats positively but did not provide the expected housing, feeding and medications as practiced in more advanced countries.
\end{abstract}

Keywords: Domestic House Cat; Questionnaire; Ownership; Myths; Maiduguri

\section{Introduction}

Cat ownership or keeping is a beautiful phenomenon practiced by humans across the globe. The domestic house cat is one of the most popular animal species kept in households across the different continents of the world for various reasons. Cats are kept as companion, pets or rodent catchers [1]. In some parts of the world, cats are considered as family members [2]. Love and familiarity for cats remains an enigma, as the cat is friendly to humans and yet remains introverted [1]. The wellbeing of the domestic house cat can be greatly compromised by problems like natural disasters, automobile accidents and the transmission of zoonotic and contagious diseases [3]. The significance of animal population records in relation to abundance, spatial distribution and demographic structure is vital for planning and decision making for government and industry [4]. Moreso, adequate veterinary care, restriction of animal movement, selective reproduction, adequate regulations and education of owners can provide positive experience for pet ownership [5].

The official feline population data are not available worldwide because the cat census is not usually recognized as a significant asset for public health [6]. However, understanding the dynamics of the urban feline population is fundamental for the implementation of control programs for zoonotic and infectious diseases [3].

Demographic surveys of pet animals have been performed in many countries like Canada [7], Zimbabwe [8], Kenya [9], Ireland [10], Australia [11], and Guatemala [12]. Information regarding demographics of cat population and ownership profile is lacking or not available in Nigeria. Factors such as age, diets, neutering, veterinary visits, sources of cats, management system, vaccination etc. represents crucial issues for epidemiological studies [11]. An accurate estimate of the size and features of an animal population is very vital to address health (animal/human) policies properly. Myths and cultural beliefs have been attributed to the domestic house cats. During the middle Ages, cats became associated with witches, warlocks and were linked with demonic worships [13]. As a result the domestic house cat has suffered persecutions and is still remains the most persecuted amongst the domestic animal species in some parts of the world. The Kanuri people, who are the major residents of Maiduguri, Nigeria, believe that witches and wizards can cause mayhem and could turn to cats through supernatural powers at night [14]. Similarly, in the Ibibio culture of southeastern Nigeria, cats are viewed as the agents of the devil. They also believe that witches transform to cats at night [15]. Thus, this study was conducted to provide baseline data on the human-cat relationship, associated myths/superstitions and its consequences on cat ownership in Maiduguri using an on spot questionnaire, administration. 


\section{Materials and Methods}

\section{Study Area}

This study was carried out in Maiduguri, the capital of Borno state. Borno state lies between latitude $11^{0} 32^{1}$ and $11^{0} 4^{1}$ North and longitude $13^{0} 32^{1}$ and $13^{0} 25^{1}$ East with an area of $69,435 \mathrm{~km}^{2}$. It is located between the Sudan savannah and Sahel savannah vegetation zones. The climate is characterized by two distinct seasons, with a yearly uni-modal rainfall pattern. The climate is generally very hot $\left(\geq 44^{\circ} \mathrm{C}\right)$ with mean annual rainfall of between $200-250 \mathrm{~mm}$. The inhabitants of Maiduguri are mostly Muslims and the major ethnic group is the Kanuri $[16,17]$.

\section{Pretesting and Recruitment of Participants}

Pre-survey visits were carried out to identify households with cat(s), to interact with residents and obtain their consent to participate in the study. Consent was obtained through verbal acceptance to participate in the study by responding to general questions and availing their cat(s) for examination. Appointment was made with consenting cat owners to make them available for the interview. The houses of consenting cat owners were marked for ease of identification during the proper study.

\section{Sampling and Data Collection}

The current study was carried out to identify cat owning households in Maiduguri metropolis. Two hundred households from four major wards were surveyed (Hausari, Shehuri, Mairi and Bulumkutu wards), in each ward, 50 households were randomly selected. This study was carried out from January to July 2008.

A structured close-ended questionnaire was designed consisting of 5 parts. Part 1 of the questionnaire solicited information on the respondent, part 2 dwelled on specific information on the cat e.g. age, sex, number in household, vaccination history, veterinary visits, neutered or intact etc. whereas part 3 sought for information on diseases and signs of disease awareness. Part 4 sought to know the frequency and rate of kittening, while part 5 requested information on myths/superstitions associated with the house cat.

The questionnaires were issued to the owners of the cats in each household. If the owner of the cat is not literate, the questions were read and translated to the respondent in his/her local dialect and the answers provided were filled in by the interviewer.

Data were analyzed with Graph Pad InStat ${ }^{\oplus}$ (2003). Relationships between nominal variables studied and responses were analyzed using descriptive and inferential (Chi-square) statistics. Values were considered significant at $\mathrm{P}<0.05$.

\section{Results}

The overall response rate was $98.0 \%$. Out of the 200 households randomly selected for the survey, 196 (98.0\%) participated, while $4(2.0 \%)$ turned down participation in the survey. Of the 196 households that participated in the survey, (84.0\%) owned cats, while (14.0\%) did not own a cat. Elderly women, children and young ladies owned 55.5\%, 35.0\% and 3.5\% respectively. Three hundred and ten (310) cats were owned by the 168 households. Of these 310 cats, $86.1 \%$ were females and $13.9 \%$ were males. Only 1 male was neutered.

Table 1 show that majority of households (70.8\%) in Maiduguri owned only one cat and $10.7 \%$ owned more than 3 . In addition, $75.0 \%$ of the households kept cats to control rodents in their homes.

\begin{tabular}{|c|c|}
\hline Variables & Number (\%) \\
\hline $\begin{array}{c}\text { Number of cat(s) per } \\
\text { household }\end{array}$ & $119(70.8)$ \\
\hline 1 & $31(18.5)$ \\
\hline 2 & $18(10.7)$ \\
\hline$>2.0$ & $126(75.0)$ \\
\hline Reasons for keeping cats & $30(17.9)$ \\
\hline Control of rodents & $7(4.2)$ \\
\hline Companionship & $5(2.9)$ \\
\hline Love for cats & rodents \\
\hline $\begin{array}{c}\text { Companionship and control of } \\
\text { rodep }\end{array}$ &
\end{tabular}

Table 1: Number of Cats Per Household And Reasons For Keeping Cats In Maiduguri

Significantly higher $(\mathrm{P}<0.05)$ number of respondents in the study were not knowledgeable about different cat breeds, and only (2.9\%) made deliberate efforts to breed their cats. Furthermore, significantly more households were neither aware of cat diseases, nor presented their cats to veterinary clinics or ever vaccinated their cats (Table 2). In addition, (92.8\%) households allowed their cats to be indoors or outdoors at will and the cats were fed with table scraps and leftovers.

Majority of the respondents (89.2\%) have no idea on the frequency of kittening and (96.4\%) of them gave out their kittens to interested households. Among the respondents, (2.9\%) consume cat meat (Table 3 ). Table 4 shows some of the myths associated 


\begin{tabular}{|c|c|c|c|}
\hline Variables & \multicolumn{2}{|c|}{ Responses (n-196) } & Significance \\
\hline \multirow{2}{*}{ Knowledge of breed } & Yes & No & \multirow{2}{*}{$\mathrm{P}<0.05$} \\
\hline & $0(0.0)$ & $168(100.0)$ & \\
\hline \multirow{2}{*}{ Breeding method } & Selective & Do not care & \multirow{2}{*}{$\mathrm{P}<0.05$} \\
\hline & $5(2.9)$ & $163(97.0)$ & \\
\hline \multirow{2}{*}{ Disease awareness } & Aware & Not aware & \multirow{2}{*}{$\mathrm{P}<0.05$} \\
\hline & $71(42.3)$ & $97(57.7)$ & \\
\hline \multirow{2}{*}{ Veterinary visit } & Yes & No & \multirow{2}{*}{$\mathrm{P}<0.05$} \\
\hline & $13(7.7)$ & $155(92.3)$ & \\
\hline \multirow{2}{*}{ Vaccination } & Yes & No & \\
\hline & $0(0.0)$ & $168(100.0)$ & \\
\hline \multicolumn{2}{|c|}{ Management } & & \multirow{4}{*}{$\mathrm{P}<0.05$} \\
\hline Indoor & $9(5.4)$ & & \\
\hline Outdoor & $3(1.8)$ & & \\
\hline Indoor/outdoor & $156(92.8)$ & & \\
\hline \multicolumn{2}{|c|}{ Types of food } & & \multirow{4}{*}{$\mathrm{P}<0.0001$} \\
\hline Commercial & $0(0.0)$ & & \\
\hline Special diet & $14(8.3 \%)$ & & \\
\hline Table scraps/leftover & $154(91.7)$ & & \\
\hline
\end{tabular}

Table 2: Breed identification, disease awareness, veterinary care, management and types of food fed to cats by households keeping cats in Maiduguri with household cats in Maiduguri. Households, not keeping cats had more superstitious beliefs than households keeping cats.

\begin{tabular}{|c|c|}
\hline Variables & $\begin{array}{c}\text { Number } \\
(\%)\end{array}$ \\
\hline $\begin{array}{c}\text { Kittening times per } \\
\text { year }\end{array}$ & $3(1.8)$ \\
\hline 1 & $15(8.9)$ \\
\hline 2 & $150(89.2)$ \\
\hline No idea & $162(96.4)$ \\
\hline $\begin{array}{c}\text { Attitude towards the } \\
\text { kittens }\end{array}$ & $0(0.0)$ \\
\hline Give out & $6(3.6)$ \\
\hline Sale & $163(97.0)$ \\
\hline Abandon
\end{tabular}

Table 3: Frequency of kittening and attitude of cat owner's to the kittens

\begin{tabular}{|c|c|c|c|}
\hline Myths/superstition & $\begin{array}{c}\text { Number } \\
(\%)\end{array}$ & $\begin{array}{c}\text { Number of } \\
\text { Households } \\
\text { keeping cats } \\
\text { (\%) }\end{array}$ & $\begin{array}{c}\text { Number of } \\
\text { Households } \\
\text { Not keeping } \\
\text { cats (\%) }\end{array}$ \\
\hline $\begin{array}{c}\text { Cat hair (fur) causes } \\
\text { tuberculosis on } \\
\text { ingestion }\end{array}$ & $25(12.8)$ & $5(2.6)$ & $20(10.2)$ \\
\hline $\begin{array}{c}\text { Witches transform to } \\
\text { cats at night }\end{array}$ & $29(14.8)$ & $11(5.6)$ & $18(9.2)$ \\
\hline Black cats are bad luck & $12(6.1)$ & $1(0.5)$ & $7(3.6)$ \\
\hline $\begin{array}{c}\text { Male cats are } \\
\text { associates of the devil } \\
\text { and evil spirits }\end{array}$ & $10(5.1)$ & $3(1.5)$ & $6(3.1)$ \\
\hline $\begin{array}{c}\text { Cats cause impotency } \\
\text { in male babies and } \\
\text { bareness in women }\end{array}$ & $8(4.1)$ & $2(1.0)$ & $7(3.6)$ \\
\hline
\end{tabular}




\section{Discussion}

This survey on human-cat relationship is the first account on cat ownership in Maiduguri, Nigeria. The result of the survey showed that cats are kept by households under different management practices, myths and intentions. In the current study, cats are owned mostly by elderly women. This is probably because majority of these elderly women are lonely and the presence of these cats curb loneliness and provide meaningful daily activities for them. Similarly, a previous study by [18] had reported that households comprising only female adults were more likely to own a cat. In addition $[6,10,19]$ reported similar findings. This study also revealed that 168 households owned 310 cats. Of these 310 cats, only $0.3 \%$ was neutered. This could likely be associated with the level of awareness and perhaps inability or unwillingness to pay for veterinary health care. In contrast, studies in Perth (Australia) have shown that $84.5 \%$ of cats were neutered [20]; similar to reports of other surveys in Canada $71 \%$ [7] and 6.5\% in Brazil [3]. Unneutered male cats have been found to be more aggressive and as such are more exposed to the risk of roaming, disease transmission and automobile accidents [21-23].

These risks can be greatly reduced if movements of these cats are restricted and selective reproduction are practiced by cat owners. Females accounted for the highest number of cats in this study (86.1\%) than the males (13.9\%) and thus agrees with the findings of [11] in Sydney, where the females represented 55.0\% of the cats they studied. Furthermore, in Ireland, 56.3\% of the cats surveyed were females [10]. A greater percentage of households during this study maintained a single cat similar to what was obtained in UK households [19]. However, most of the cats in the current study had access to the outside and were not neutered thereby increasing the risk of unplanned pregnancies, disease transmission and automobile accidents. A small percentage of the households kept cats for companionship. Interaction with the cat owners revealed obvious benefits in relation to cat keeping such as reducing loneliness and a source of meaningful daily activities as was similarly reported by [24]. Furthermore, a significant percentage of the households kept cats for the control of rodents. For long periods of time, cats were primarily valued for their role in the control of the rodent population [25].

In all the 168 households owning cats, none of the owners had an idea of the breed(s) of cats. Cats in Nigeria have not been characterized into breeds and are commonly referred to as "mongrels" or local breeds. There is therefore the need for further studies to characterize the Nigerian cats [26]. In a similar study carried out by [3] in southern Brazil $81.2 \%$ of the cats were without any definite breed. Majority of the households (97.1\%) allowed their cats to mate indiscriminately with only very few households $(2.9 \%)$ that controlled the breeding of their cats. The uncontrolled breeding of these cats probably contributed to their being unclassified to any specific breed.

Most of the households (57.7\%) were not aware of the diseases of the domestic house cat and this may partly explain why these (92.3\%) have never visited a veterinary hospital. This result is in contrast to the findings of [11] in Sydney, where $90 \%$ of cats have attended a veterinary hospital. In addition [6], reported $43.3 \%$ of cats in Italy have visited a veterinary hospital one to two times in a year. The findings in the current study suggested that most cat owners do not seek regular veterinary services which negate the wellbeing of these cats. All the cats in the household surveyed, 168 (100\%) had never been vaccinated against any of the preventable feline diseases similar to the findings of [3] in which 91.5\% of the pet cats in a city of Southern Brazil were also not vaccinated against any specific disease. However, in contrast to a similar study conducted in Australia, $97 \%$ of cats have been vaccinated at least once in their life time [11]. This further buttresses the need for awareness of cat owners on the importance of vaccination against the preventable diseases affecting these species with fatal consequences if neglected. Several of the households surveyed (92.8\%) allowed their cats access to both the outdoor and indoor similar to the findings of [3] in Brazil. Most of the outdoor cats were sexually intact and had never been vaccinated and were therefore more susceptible to contagious diseases and automobile accidents. Cats in this study (91.7\%) were fed with table scraps or leftover. These foods consisted of carbohydrate (Maize grits/ paste), vegetable soups and pieces of meat or fish, while $(8.3 \%)$ were fed "special" diet. The cat owners considered it "special" because these cats had separate pots and their meals are prepared by the owners. However, the constituents of these 'special' diet does not differ from the table scraps or leftovers. None of the cats were fed with commercial food. This was however in contrast to their exotic counterparts that were fed high calory commercial diets [27-29]. Furthermore, most of the cats seen in the current study as claimed by most cat owners were adequately fed and some of the cats supplemented their feed by hunting rodents and lizards. A larger population of the households keeping cats $(89.2 \%)$ has no idea on the rate of kittening in a year with majority (94.4\%) giving out the kittens to other interested households. Selling cats is against the culture and religious beliefs of the people in the study area, while (3.6\%) abandoned the kittens in public places and outskirts of the city. This act is particularly disturbing with regards to welfare and wellbeing of these helpless kittens, because those that survived may add to the stray population. Pets are supposed to be loved by humans but not to be consumed. However, a small percentage of the household (2.9\%) ate cat meat as a delicacy, and also believes in its ability to heal certain diseases and protect against evils. Myths and cultural beliefs probably contributed as to why cats are not kept by some households. Most of these households irrespective of owning a cat or not, or their educational background believed in some myths associated with the house cat. One such myth is that "cat hair on ingestion causes tuberculosis". This belief remains unsubstantiated as the agents of tuberculosis are transmitted through contact with infected animal or man or ingestion of contaminated milk and meat. Another of the myths among the respondents is that witches transformed into cats at night which appears to support the general belief that witchcraft is universal [30]. Witches possess inherent psychic power to send out their spirits invisibly or through lower creatures to harm others [31]. Underlying this belief is the idea that the human soul could exist independently of the material body. At night, this soul quits the body and assumes the form of a creature to carry out evil acts against others [32]. Black cats were considered as bringing bad luck by the respondents during the study whereas in 
the Ibibio culture of southeastern Nigeria, the black cats were also considered as agents of the devil [15].

Such beliefs have survived in the history of many nations and seems to form the bedrock of many superstitions and legends [13]. However, keeping cats appears to be an acceptable cultural practice among residents in Maiduguri, inspite of the underlying handicaps.

\section{Conclusion}

It was concluded that elderly women and children owned cats in the households studied. Furthermore, significantly more owners were unaware of cat diseases and failed to present their cats to veterinary clinics or vaccinated their cats. The cats were allowed free access to outdoors and survived on rodents as well as table scraps. Cat keeping is an acceptable cultural practice despite existence of some superstitious beliefs. It is envisaged that cat welfare would improve with increased disposable income of households in Maiduguri, Nigeria. There is need for further comprehensive and large scale research on cat ecology and other sociocultural background of cat owners in Nigeria.

\section{Acknowledgement}

This study was supported by a grant from the STEP - B Project IOT 2010 (Innovators of Tomorrow) Federal Ministry of Education Nigeria. The authors also wish to acknowledge Dr. M.M. Bukar and Dr. L. Adamu for their assistance during the preparation of this manuscript.

\section{References}

1. Dennis CT, Patrick B (2000) The Domestic Cat: The biology of its behavior (2nd Edn) Cambridge University Press, UK.

2. Passantino A, Masucci M (2016) Congenital and Inherited Neurologic Diseases in Dogs and Cats: Legislation and its effect on purchase in Italy. Vet World 9: 437-43.

3. Trapp SM, Castilho de Faria Maeda MS, Kemper B, Barca Junior FA, Freire RL, et al. (2015) Population Demographic Survey and Ownership of pet dogs and cats from a small city of southern Brazil. Ciencias Agrarias 26: 3211-26.

4. Nasser R, Mossier JE (1991) Projection of Pet Populations from Census Demographic Data American Veterinary Association 198: 1157-9.

5. Canatto BD, Silva EA, Bernardi F, Mendes MCNC, Paranhos NT, et al. (2012) Demographic characterization of supervised dog and cat populations in Sao Paulo city, Brazil [Caracterizaçāo demmográfica das populaçōes des cãese gatos supervisionados do municipio de são Paulo]. Arquivo Brasileiro de Medicina Veterinária e Zootecnia, Belo Horizonte 64: 1515-23.

6. Carvelli A, Lacoponi F, Scaramozzino P (2016) A Cross Sectional Survey to Estimate the Cat Population and Ownership Profiles in a Semi Rural Area of Central Italy. Biomedical Research 10.1155/2016/3796872.

7. Leslie BE, Meek AH, Kawash GF, McKeown DB (1994) An Epidemiological Investigation of Pet Ownership in Ontaria. Can Vet J 35: 218-22.

8. Butler JR, Bingham J (2000) Demography and Dog-Human Relationships of the Dog Population in Zimbabwean Communal Lands. Vet Record 147: $442-6$.

9. Kitala P, McDermott J, Kyule M, Gathuma J, Perry B, et al. (2001) A Dog Ecology and Demography Information to Support the Planning of Rabies control in Machakos District Kenya. Acta Trop 78: 217-30.

10. Downes MJ, Canty MJ, More SJ (2009) Demography of the Pet Dog and Cat Population on the Island of Ireland and Human Factors Influencing Pet Ownership. Prev Vet Med 92: 140-9.

11. Toribio JA, Norris, JM, White JD, Dhand NK, Hamilton SA, et al. (2009) Demographics and Husbandry of Pet Cats living in Sydney, Australia: results of a cross sectional survey of pet ownership. J Feline Med Surg 11: 449-61.

12. Pulczer AS, Jones-Bitton A, Waltner-Toews DJ, Dewey CE (2003) Owned Dog Demography in Todos Santos Cuchumatan, Guatemala. Prev Vet Med 108: 20917.

13. James AS (2000) Domestication and History of the Cat In: The Domestic Cat: The biology of its behavior. ( $2^{\text {nd }}$ Edn), Cambridge University Press, UK.

14. Potiskum MS (2017) The Kanuri Ethnic Nationality. In: Ayittey GN. The Kanuri Empire, Nigeria.

15. Gall PO (1984) The phenomenon of witchcraft among the Ibibio people of Nigeria.Pontificia Universitas Urbaniana, Facultas Philosophica, USA.

16. Carter RC (1994) The Groundwater Hydrology of the Manger Grasslands, Northeastern Nigeria: Importance to agricultural development strategy of the area. Quarterly J Engin Geo Hydrol 27: S73-83.

17. NIMET (2017) Nigeria Meteorological Agency, Nigeria.

18. Wesgarth C, Pinchbeck GL, Bradshaw JW, Dawson S, Gaskell RM, et al. (2010) Factors associated with cat ownership in communities in the UK. Vet Record 166: $354-7$.

19. Murray JK, Browne WJ, Roberts MA, Whitmarsh AJ, Gruffydd-Jones TJ (2010) Number and Ownership Profiles of Cats and Dogs in the UK. Vet Record 166: 163-8.

20. Robertson ID, Edwards JR, Shaws SE, Clark WT (1990) A Survey of Pet Ownership in Perth. Aus Vet Practice 20: 210-4.

21. Love DN, Malik R, Norris, JM (2000) Bacteriological Warfare Amongst Cat: what have we learned about cat bite infection? Vet Microbiol 74: 179-93.

22. Slater MR (2001) The Role of Veterinary Epidemiology in the study of free-roaming dogs and cats. Prev Vet Med 48: 273-86.

23. Malik R, Vogelnest L, O'Brien CR, White J, Hawke C, et al. (2004) Infections and some other conditions affecting the skin and subcutis of the nasoocular region of cats-clinical experience 1987-2003. J Feline Med Surg 6: 383-90.

24. Beck AM, MeyersNM (1996) Health Enhancement and Companion Animal Ownership. Annu Rev Public Health 17: 247-57.

25. Dennis CT, Mike BF (2000) Hunting Behavior of Domestic Cats and their Impact on Prey Populations In: The Domestic Cat: the biology of its behavior (2nd Edn) Cambridge University Press, UK.

26. Bukar-Kolo YM, Grema HA, Sanda KA, Balami AG, Gambo BG, et al. (2014) Morphologic and Morphometric Features of Domestic Cats Native to Maiduguri Semi Arid Region of North-Eastern Nigeria. Sahel Journal of Veterinary Science 13: 7-11. 
27. Zoran DL (2002) The Carnivore Connection to Nutrition in Cats. J Am Vet Med Assoc 221: 1559-67.

28. Bartge JW, Kirt CA (2006) Nutrition and Lower Urinary Tract Diseases in Cats. Vet Clin North Am Small Anim Pract 36: $1361-76$.

29. German AJ (2006) The Growing Problem of Obesity in Dogs and Cats. J Nutr 136: 1940S-6S.

30. Frazier B (1992) The Golden Bough. New York Macmillan, UK.

31. Sanders G (2015) Witchcraft Beliefs and Accusations in Africa. Africa World Press 3.

32. Archibong EP, Enang EE, Bassey GE (2017) Witchcraft Beliefs in Diseases Causation and Health seeking Behaviour in Pregnancy of Women in Calabar SouthNigeria. IOSR J Humanities Soci Sci 22: 24-8

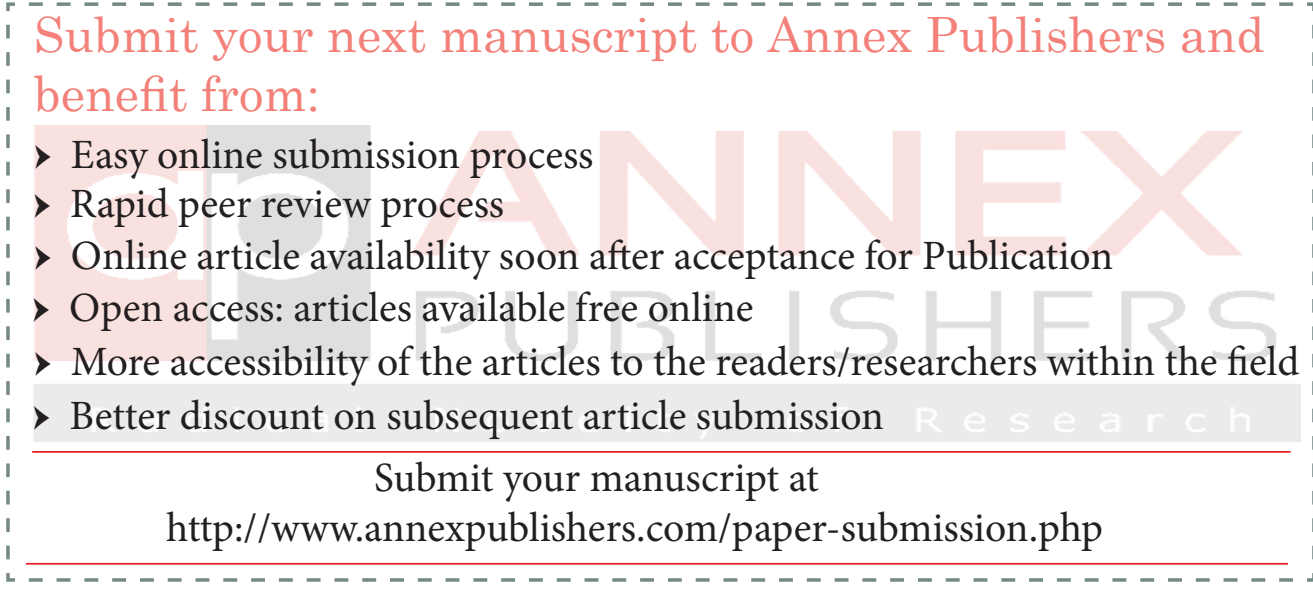

